\title{
Changes In Stock Returns And Trading Volume Of American Depositary Receipts Around Their U.S. Stock Exchange Listing Switches
}

Kam C. Chan, Pace University, USA

Annie Wong, Western Connecticut State University, USA

\begin{abstract}
This study examines the change in stock returns and trading volume of American Depositary Receipts when foreign firms switched their listings from a major U.S. stock exchange to a more prestigious U.S. stock exchange; namely from the NASDAQ or American Stock Exchange to the New York Stock Exchange or from the American Stock Exchange to the NASDAQ since year 2000. We find that the stock returns of these American Depositary Receipts changed from better-thanmarket performance before the listing changes to just market performance after the listing changes. This evidence is consistent with a timing behavior of the management. We also find significant increase in their trading volume after the listing changes. This leads us to conclude that switching to a more prestigious stock exchange was able to create more investor interest.
\end{abstract}

Keywords: American Depositary Receipts; Changes in Stock Returns and Trading Volume

\section{INTRODUCTION}

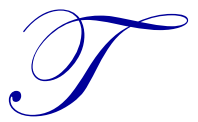

he rapid globalization of financial markets is reflected by the increasing number of foreign firms that cross-listed their shares in the U.S. as American Depositary Receipts (ADRs). An ADR represents a certain number of underlying shares of a foreign firm in a foreign country. ADRs provide a convenient way for U.S. investors to invest in foreign companies. Chan et al. (1996) find that the trading costs of ADRs are comparable to that of U.S. firms. Among the major stock exchange listings, listings on the New York Stock Exchange (NYSE) and American Stock Exchange (ASE) have been traditionally considered as more prestigious than listings on the NASDAQ even though the ASE has been losing its market share in stock listings since the mid-90s [Aggarwal and Angel (1999) and Chan and Wong (2004)].

Studies on the value of exchange listing have consistently found positive stock price reactions to announcements of exchange listing on the NYSE and the ASE [Van Horne (1970), Ying et al. (1977), Fabozzi (1981), and Sanger and McConnell (1986)]. The positive market reactions imply that listing on the NYSE/ASE increases firm value. Several studies suggest that better liquidity is one source of value of NYSE/ASE listing. Kadlec and McConnell (1994) find that firms formerly listed on the NASDAQ experience significant decrease in their absolute and relative bid-ask spreads after listing on the NYSE or the ASE. Grammatikos and Papaioannou (1986) and Edelman and Baker (1991) examine the stock price reactions to announcements of NYSE/ASE listing by the NASDAQ firms. They conclude that the market reaction is more positive for firms with lower pre-listing liquidity. Other studies suggest that increased visibility is another source of value of exchange listing. Kadlec and McConnell (1994) find that firms switched from the NASDAQ to the NYSE have more registered shareholders and institutional shareholders afterward.

Many studies have consistently shown that firms changed from the NASDAQ to the NYSE/ASE have poor stock returns after the listing changes. For example, Dharan and Ikenberry (1995) examine the stock performance of 
U.S. firms after they switched from the NASDAQ to the NYSE/ASE in 1962-90. They find a decline in stock returns in the first three years after the switch. They also report that the average stock price reaction to the first 12 quarterly earnings announcements after the listing change is $-4.83 \%$. This shows that the average earnings performance of the firms is disappointing after the listing changes. This is consistent with the opportunistic behavior of firms switching to more prestigious exchanges at the peak of their performance due to the higher earnings and other requirements for being listed on the NYSE and the ASE than those for being listed on the NASDAQ.

The primary objectives of this study are to examine the stock returns and trading volume of ADRs after their listing changes from the NASDAQ/ASE to the NYSE. We also include exchange listing changes from the ASE to the NASDAQ since year 2000 because of the decline of the ASE and the emergence of the NASDAQ as a more prestigious stock exchange in the last two decades. This study contributes to the literature in several ways. First, while prior studies have examined the listing changes of U.S. domestic firms, this study extends the literature by examining the effects of ADR listing changes in major U.S. stock exchanges for foreign firms. Similar to U.S. firms, foreign firms often mention that the key reason of ADR listing changes is to enhance their profile to U.S. investors. Below is an excerpt of the press release of Signet Group regarding its listing change from the NASDAQ to the NYSE in 2004.

Terry Burman, Group Chief Executive, commented: "Signet is committed to raising its profile among US investors. Listing on the NYSE will provide an excellent platform to highlight to the US financial community our consistent record of growth, excellence in operational execution and culture of continuous improvement, these being the drivers behind our financial performance. Signet has a market capitalization of $\$ 3.4$ billion. The US division, which accounts for some $70 \%$ of sales and operates under strong brand names such as "Kay Jewelers" and "Jared The Galleria Of Jewelry", offers significant further growth opportunities. We believe that Signet's profile will be of interest to an increasing number of potential US investors."

"The NYSE is proud to welcome Signet to our family of listed companies," said NYSE CEO John Thain. "Signet is a recognized market leader with an impressive portfolio of retail brands in America and abroad. Signet will be a strong addition to our roster of top retail sector players. We look forward to an outstanding partnership with Signet and its shareholders."

Second, foreign firms with ADR listings are typically large multinational firms. Thus, it is interesting to examine whether these large foreign firms also need to time their exchange listing changes at the peak of their firm performance. If they did, we should observe negative stock returns performance in the period after the listing changes. On the other hand, if these firms mainly changed their listings to improve the liquidity of the ADRs and visibility of the firms, their stock returns after the moves should not be negative. Second, we examine if these foreign firms changed exchange listing for better visibility in order to increase trading volume of ADRs. The findings of this study bear significant economic implications for the investment decisions of U.S. investors.

\section{RESEARCH DESIGN}

An initial sample of ADRs was extracted from the Center for Research in Security Prices (CRSP) database. The exchange listing history of the ADRs was collected from the CRSP and a sample of ADRs that changed listing among the NYSE, ASE, and NASDAQ in 1970-2007 was identified. To be included in the final sample, an ADR must have sufficient stock return and trading volume data as defined below.

We examined the stock performance of the sample firms before and after the listing changes in order to determine if they timed their moves at the peak of firm performance. The stock performance of the sample firms was analyzed using the 4-factor model with pricing factors suggested by Fama and French (1993) and Carhart (1997) as follows:

$\mathrm{R}_{\mathrm{it}}-\mathrm{R}_{\mathrm{ft}}=\alpha+\mathrm{b}\left(\mathrm{R}_{\mathrm{mt}}-\mathrm{R}_{\mathrm{ft}}\right)+\mathrm{sSMB}_{\mathrm{t}}+\mathrm{hHML}_{\mathrm{t}}+\mathrm{uUMD} \mathrm{D}_{\mathrm{t}}+\varepsilon_{\mathrm{t}}$

where 
$\mathrm{R}_{\mathrm{it}} \quad=$ daily stock return of ADR $\mathrm{i}$ on day $\mathrm{t}$;

$\mathrm{R}_{\mathrm{ft}} \quad=$ one month Treasury bill interest rate on day $\mathrm{t}$;

$\mathrm{R}_{\mathrm{mt}} \quad=$ daily return of the CRSP value-weighted index on day $\mathrm{t}$;

$\mathrm{SMB}_{\mathrm{t}}=$ daily return of the small-minus-big size portfolio on day $\mathrm{t}$;

$\mathrm{HML}_{\mathrm{t}}=$ daily return of the high-minus-low book-to-market portfolio on day $\mathrm{t}$; and

$\mathrm{UMD}_{\mathrm{t}}=$ daily return of the momentum portfolio on day $\mathrm{t}$.

This model was estimated for each sample firms twice. First, the model was estimated using daily returns in the 500 trading days before their listing changes. Second, the model was estimated again using daily returns in the 500 trading days after their listing changes. The daily returns on the ADRs, CRSP value-weighted index, and Treasury bills were collected from the CRSP. Daily returns for the size, book-to-market, and momentum portfolios were collected from the Fama and French database at the Wharton Research Data Services. The intercept $\alpha$ measures the abnormal return of each firm in each of the two 500-day periods. We analyzed if the average $\alpha$ among the sample firms is statistically positive or negative. An average positive (negative) $\alpha$ suggests that the sample firms over-(under-)performed in the stock market after adjusted for their risk factors. If these firms timed their listing changes at the peak of their stock performance, we should observe the average $\alpha$ changing from positive before the listing changes to negative after the listing changes.

We also examined if firms changed their listings in order to increase investor interest. Investor interest is measured as the ADR's trading volume. Trading volume of the two years before and after the NYSE listing was collected from the CRSP. Daily trading volume is defined as daily closing stock price multiplied with the number of shares traded.

\section{EMPIRICAL FINDINGS}

Forty foreign firms with ADR listings in the NYSE, ASE, and NASDAQ were found to have changed listings among these three major U.S. stock exchanges in 1970-2007. Only thirty-eight were included in the final sample because two firms had insufficient return data for the analysis. The sample distributions are summarized in Table 1. Panel A of the table shows the types of listing changes. Almost all of the changes were from the NASDAQ to the NYSE with six exceptions. One firm moved from the NASDAQ to the ASE in 1990 and four firms moved from the ASE to the NYSE. One firm switched from the ASE to the NASDAQ in 2006 when the NASDAQ stock listing has already been considered more prestigious than that of ASE since the mid-90s. This firm was included in the final sample. Panel B shows that the U.K. has the largest number of firms in the sample since U.K. is one of the countries with most ADR listings in the U.S. stock exchanges. Seven of the sample firms are from Japan. Legal bonding and reputational bonding are often being cited as key reasons for foreign firms to list their shares in the U.S. [Stulz (1999), Coffee (1999, 2002), and Siegel (2005)]. Since almost all of the sample firms are from developed countries, it is unlikely that better bonding mechanism is the reason for the listing changes. Panel C presents the sample distributions by time periods. Most of the listing changes among the sample firms occurred in the 80s and 90 s.

Stock performance of the sample is analyzed by focusing on the intercept of the 4-factor model. The findings are reported in Table 2. Day 0 is defined as the first trading day after the listing change. For all three preswitch periods of days -1 to $-500,-1$ to -250 , and -251 to -500 , the average and median intercepts are positive and statistically significant. This suggests that these foreign firms have positive risk-adjusted stock returns in the two years before the switches. However, the average and median intercepts of the 4-factor model are mostly negative but insignificant in the two years after the switches. The overall pattern of the results indicates that the stock performance of the sample firms changed from over performance before the listing moves to average performance after the moves. Prior studies of U.S. firms find that their stock performance is significantly negative after the listing changes from the NASDAQ to the ASE or to the NYSE. Although the stock performance of the foreign firms is not negative after the listing changes, it is not as positive as the stock performance before the changes. Thus, there is mild evidence that large and multinational firms also timed their moves to more prestigious stock exchanges when their firm performance was at peak. 
Table 1

Sample Distributions

Panel A: sample distribution by type of listing changes

\begin{tabular}{lr} 
NASDAQ to NYSE & 32 \\
NASDAQ to ASE & 1 \\
ASE to NYSE & 4 \\
ASE to NASDAQ & \multicolumn{1}{c}{ Total }
\end{tabular}

Panel B: sample distribution by countries

\begin{tabular}{lr} 
Australia & 2 \\
Chile & 1 \\
Denmark & 1 \\
Indonesia & 1 \\
Ireland & 3 \\
Italy & 1 \\
Japan & 7 \\
Netherlands & 3 \\
Norway & 1 \\
South Africa & 3 \\
Switzerland & 1 \\
United Kingdom & 14 \\
\multicolumn{1}{c}{ Total } & 38
\end{tabular}

Panel C: sample distribution by periods

$\begin{array}{rrr}1970-79 & & 3 \\ 1980-89 & & 11 \\ 1990-99 & & 16 \\ 2000-07 & & 8 \\ & \text { Total } & 38\end{array}$

Table 2

Results of Stock Return Analysis Using the 4-factor Model

(Sample size $=38$ firms)

\begin{tabular}{|c|c|c|}
\hline \multicolumn{3}{|c|}{ Intercept of the 4-factor model $^{\mathrm{a}}$} \\
\hline Periods $^{b}$ & Mean $^{\mathrm{c}}$ & Median $^{d}$ \\
\hline Days -1 to -500 & $\begin{array}{c}0.000849 \\
(0.0001)\end{array}$ & $\begin{array}{c}0.000556 \\
(0.0001)\end{array}$ \\
\hline Days -1 to -250 & $\begin{array}{c}0.000782 \\
(0.0045)\end{array}$ & $\begin{array}{c}0.000534 \\
(0.0044)\end{array}$ \\
\hline Days -251 to -500 & $\begin{array}{c}0.000840 \\
(0.0028)\end{array}$ & $\begin{array}{c}0.000650 \\
(0.0010)\end{array}$ \\
\hline Days 0 to 499 & $\begin{array}{r}-0.00020 \\
(0.8384)\end{array}$ & $\begin{array}{r}-0.00001 \\
(0.7274)\end{array}$ \\
\hline Days 0 to 249 & $\begin{array}{c}-0.00032 \\
(0.3328)\end{array}$ & $\begin{array}{l}0.00000 \\
(0.5448)\end{array}$ \\
\hline Days 250 to 499 & $\begin{array}{l}-0.00005 \\
(0.8384)\end{array}$ & $\begin{array}{l}0.00027 \\
(0.5259)\end{array}$ \\
\hline
\end{tabular}

a: $\mathrm{R}_{\mathrm{it}}-\mathrm{R}_{\mathrm{ft}}=\alpha+\mathrm{b}\left(\mathrm{R}_{\mathrm{mt}}-\mathrm{R}_{\mathrm{ft}}\right)+\mathrm{sSMB}_{\mathrm{t}}+\mathrm{hHML} \mathrm{L}_{\mathrm{t}}+\mathrm{uUMD} \mathrm{UD}_{\mathrm{t}}+\varepsilon_{\mathrm{t}}$

where

$\mathrm{R}_{\mathrm{it}} \quad=$ daily stock return of firm $\mathrm{i}$ on day $\mathrm{t}$;

$\mathrm{R}_{\mathrm{ft}} \quad$ = daily return of one month Treasury Bill on day $\mathrm{t}$;

$\mathrm{R}_{\mathrm{mt}} \quad$ = daily return of CRSP value-weighted index on day $\mathrm{t}$;

$\mathrm{SMB}_{\mathrm{t}} \quad=$ daily return of the small-minus-big size portfolio on day $\mathrm{t}$;

$\mathrm{HML}_{\mathrm{t}}=$ daily return of the high-minus-low book-to-market portfolio on day $\mathrm{t}$; and

$\mathrm{UMD}_{\mathrm{t}}=$ daily return of the high-minus-low momentum portfolio on day $\mathrm{t}$.

b: day 0 is the first trading day of the listing change

c: two-tailed $p$-value for $t$-test of sample mean in parenthesis.

$\mathrm{d}$ : two-tailed $p$-value for sign test of sample median in parenthesis. 


\section{Table 3}

Results of Trading Volume Analysis

(Sample size $=32$ firms)

Panel A: trading volume statistics

Average daily trading volume

Before listing changes

$\$ 2,710,808$

After listing changes

Median daily trading volume

$\$ 1,055,414$

$\$ 3,644,483$

$\$ 1,232,282$

Panel B: percentage change in trading volume

Average percentage change in trading volume $0.633229(0.0250)^{\mathrm{a}}$

Median percentage change in trading volume $0.219902(0.0550)^{\mathrm{b}}$

a: two-tailed $p$-value for $t$-test of sample mean in parenthesis.

b: two-tailed $p$-value for sign test of sample median in parenthesis.

The results of the change in trading volume are presented in Table 3. Among the forty sample firms, 32 of them have sufficient trading volume data in the analysis. In the 500 trading days before the listing changes, the average and median daily trading volume were about \$2.7 million and \$1 million, respectively. However, the trading volume jumped to an average of $\$ 3.6$ million and a median of $\$ 1.2$ million in the 500 trading days after the listing changes. The percentage change of the trading volume from before to after the switches is statistically significant in terms of the both the average and the median measures. This is consistent with the general perception that firms can improve investor interest from switching their stock listings to a more prestigious stock exchange. The trading volume statistic from the NASDAQ is overstated as compared to that of the NYSE and the ASE given the double counting problem associated with the NASDAQ's dealer system (Anderson and Dyl 2007). Since we only have one sample firm that switched from the ASE to the NASDAQ, the actual extent of increased trading volume after the listing changes should have been even more substantial.

\section{CONCLUSIONS}

We examine changes in stock returns and trading volume of ADRs that switched their stock listings from a major U.S. stock exchange to one that is even more prestigious in 1970-2007. Almost all of the sample ADRs are from developed countries and most of the listing changes were from the NASDAQ to the NYSE. The findings show that while these ADRs have positive risk-adjusted stock returns before the listing changes, their stock returns are not significantly positive or negative on a risk-adjusted basis after the changes. In addition, we find that there is a significant increase in trading volume of the ADRs after the listing changes. Overall, the results suggest that foreign firms switched the ADR listings from a major stock exchange to an even more prestigious U.S. stock exchange when their stock performance was at its peak. The listing changes also enabled the foreign firms to increase investor interest on the ADRs at the more prominent stock exchanges.

\section{AUTHOR INFORMATION}

Kam C. Chan is a professor of accounting at the Lubin School of Business at Pace University. He received his $\mathrm{Ph} . D$. degree from the University of South Carolina in 1991. His research interests include capital market research in auditing, financial accounting, and international accounting. He has published in top journals such as Accounting, Organizations and Society, Auditing: A Journal of Practice and Theory, Journal of Accounting and Economics, Journal of Business Finance and Accounting, Journal of International Accounting Research, and Journal of Multinational Financial Management. E-mail: kchan@pace.edu (Corresponding author)

Annie Wong is a Co-chair and Professor of Finance of the Finance Department at Western Connecticut State University. She received her Ph.D. degree in Finance from the State University of New York at Buffalo. Her primary research expertise is in the area of rate regulation for public utilities. Her research findings on this topic have been cited by expert witnesses and rate regulators in numerous court proceedings in many states. She has also published in refereed journals in the areas of investments and corporate finance. Dr. Wong is currently serving on the editorial advisory board for The Banking and Finance Review. She has won best presenter awards in conferences and was the recipient of the Ancell School of Business Outstanding Faculty Member Award at Western Connecticut State University in 2008. E-mail: wonga@wcsu.edu 


\section{REFERENCES}

1. Aggarwal, R and J. Angel, 1999, The rise and fall of the Amex Emerging Company Marketplace, Journal of Financial Economics 52, 257-289.

2. Anderson, A. and E. Dyl, 2007, Trading volume: NASDAQ and the NYSE, Financial Analysts Journal, Vol. 63, pp. 79-86.

3. Ashbaugh, H., LaFond, R., and Mayhew, B., 2003, Do nonaudit services compromise auditor independence? Further evidence, The Accounting Review, Vol. 8, pp. 611-639.

4. Carhart, M., 1997, On Persistence in Mutual Fund Performance, Journal of Finance 52, 57-82.

5. Chan, K., G. Seow, and A. Wong, 1996, Bid-ask spread of American Depositary Receipts, Journal of Multinational Financial Management, (Number 2/3): 21-30.

6. Chan, K. and A. Wong, 2004, Long-term effects following voluntarily move from American Stock Exchange to Nasdaq, Review of Accounting and Finance (Volume 3): 48-61.

7. Coffee, J., 1999, The future as history: The prospects for global convergence in corporate governance and its implications, Northwestern University Law Review 93, 641-708.

8. Coffee Jr., J., 2002. Racing towards the top?: the impact of cross-listings and stock market competition on international corporate governance. Columbia Law Review 102, 1757-1831.

9. Dharan, B. and D. Ikenberry, 1995, The long-run negative drift of post-listing stock returns, Journal of Finance, 1547-1574.

10. Edelman, R. B. and H. K. Baker, 1990, Liquidity and stock exchange listing, Financial Review 26, 231249.

11. Fabozzi, F. J., 1981, Does listing on the AMEX increase the value of equity? Financial Management 10, 43-50.

12. Fama, E. F. and K. R. French, 1993, Common Risk Factors in the Returns on Stocks and Bonds, Journal of Financial Economics 33, 3-56.

13. Grammatikos, T. and G. J. Papaioannou, 1986, Market reaction to NYSE listings: Tests of the marketability gains hypothesis, Journal of Financial Research 9, 215-227.

14. Kadlec, B. and J. McConnell, 1994, The effect of market segmentation and illiquidity on asset prices: Evidence from exchange listings, Journal of Finance 49, 611-636.

15. Sanger, G. C. and J. J. McConnell, 1986, Stock exchange listings, firm value, and security market efficiency: The impact of NASDAQ, Journal of Financial and Quantitative Analysis 21, 1-25.

16. Siegel, J, 2005, Can foreign firms bond themselves effectively by renting U.S. securities laws? Journal of Financial Economics 75, 319-359.

17. Stulz, R., 1999, Globalization, corporate finance, and the cost of capital, Journal of Applied Corporate Finance 12, 8-25.

18. Van Horne, J. C., 1970, New listings and their price behavior, Journal of Finance 25, 783-794.

19. Ying, L. K.W., W. G. Lewellen, G. G. Schlarbaum and R. C. Lease, 1977, Stock exchange listings and securities returns, Journal of Financial and Quantitative Analysis 12, 415-432. 